\title{
Aspectos do imaginário e da comunicação em Grande Sertão: Veredas
}

\section{Gustavo Castro Silva}

Pós-doutor; Universidade de Brasília, Brasília, DF, Brasil

gustavocastroesilva@gmail.com

\section{Resumo}

Trata-se de uma leitura crítica de imagens do livro Grande Sertão: Veredas (de 1956), com destaque para aspectos da comunicação e do incomunicável. O imaginário do livro flutua entre imagens da indeterminação, da ambiguidade e da mistura nos "entremeios": coisas-dentro-das-coisas e coisas-entre-ascoisas. $O$ artigo propõe uma problematização da relação estética do leitor e da leitura da obra, a partir da sua forma poética. Além disso, são feitas considerações sobre o imaginário e o pensamento comunicacional.

\section{Palavras-chave}

Literatura brasileira. Comunicação. Grande Sertão: Veredas. Guimarães Rosa. Entremeios.

\section{Introdução}

Neste artigo, entende-se imaginário como campo, por excelência, do estudo da noção de duplo e, por isso mesmo, domínio da problematização da relação crítica com as imagens. O duplo é a noção que abriga a própria ambiguidade, e sem a qual não podemos compreender nem as imagens nem as palavras. Os narradores midiáticos e literários sabem que toda história tem duplo sentido: entre o acontecer e o narrar, existe um jogo complexo de possibilidades, interpretações e conclusões. Pode-se, também, chamar esse duplo sentido de abertura, no sentido de uma narrativa aberta, capaz de acolher. É possível compreender, assim, que o imaginário trabalha sempre no nível do re-ver, do rememorar e do re-contar. Para Morin (2005), a palavra literária é parte de um processo estético duplo de 
projeção/identificação pelo autor, criador da obra em um primeiro momento, e pelo leitor da obra em um segundo momento:

\begin{abstract}
Entre a criação romanesca de um lado e a evocação dos espíritos por um feiticeiro ou um médium, de outro lado, os processos mentais são, até um certo grau, análogos. 0 romancista se projeta em seus heróis, como um espírito vodu que habita seus personagens, e inversamente, escreve sob seu ditado, como um médium possuído pelos espíritos (as personagens) que invocou. [...] Esse universo imaginário adquire vida para o leitor se este é, por sua vez, possuído e médium, isto é, se ele se projeta e se identifica com os personagens em situação, se ele vive neles e se eles vivem nele. (MORIN, 2005, p.78).
\end{abstract}

Guimarães Rosa era, nesse sentido, um médium, "possuído", que se "projeta e se identifica com os personagens em situação" (MORIN, 2005, p.78). Essa definição de Morin (2005), para a "criação romanesca", serve para explicar a relação entre Guimarães Rosa e Riobaldo Tatarana, no sentido em que Riobaldo é um 'vodu' feito pelo 'feiticeiro' Rosa. É a partir deste processo "mediúnico", do autor para com os seus personagens que abordaremos alguns aspectos das imagens e do imaginário em Grande Sertão: Vereda. (GSV). ${ }^{1}$ Pretende-se entender Guimarães Rosa como um medium, no sentido descrito acima, e corroborado por Baitello Júnior (2005) que atribui a esta palavra uma antiguidade, vinda do latim, origem, no português, da palavra "médium". No Brasil, passou a se escrever "mídia", transcrição da pronuncia inglesa para o plural latino de "médium", que tanto em latim quanto em inglês se escreve "media". A palavra, diz Baitello (2005), tem raiz mais profunda: na língua da qual vem o latim e quase todas as outras famílias linguísticas europeias, o indo-europeu, a palavra já existia, "medhyo", e significava "meio", "espaço intermediário", "meio de campo".

Considera-se Guimarães Rosa um pensador da comunicação, um pensador da linguagem, um crítico da estética e do establishment sócio-literário, ou, simplesmente, um poeta-escritor que problematizou literariamente o "meio de campo", o "espaço intermediário", o entre, ou a "terceira margem". Em vida, ele se interessa pelos espaços que ficam entre uma coisa e outra, os seres que ficam entre um estado e outro, as passagens, os caminhos, as travessias, o meio do caminho, ou o Tao, outra metodologia para a palavra "medhyo". Rosa reflete, explicitamente, em conto homônimo, sobre o "entremeio", sobre o Pantanal da Nhecolândia (MS). O Entremeio. Com o Vaqueiro Mariano é uma reportagem literária escrita em 1947, publicada depois em livro, em 1952, atualmente, presente no Estas

${ }^{1}$ Chamaremos o livro a partir de agora pela sua sigla, GSV. 
estórias (2015). "Entremeio" no dicionário Michaelis (1998) é (1) "intermédio"; (2) "renda bordada em tira, entre espaços lisos"; (3) "região do corpo da vaca entre as nádegas e as costas, atrás do úbere. Neste entremeio: neste meio tempo; entrementes".

A importância da noção espacial do Aberto (HEIDEGGER, 1998) e do imaginário de caminho está clara até mesmo no título que evoca a palavra "sertão", não um sertão qualquer, mas o círculo mais vasto, a abertura do Aberto, acolhedora do imponderável "Grande". Além disso, muito se poderia falar sobre o imaginário das "veredas", sendas, estradas, vias, trilhas percursos, fluxos etc. Uma dessas veredas abertas está na relação projeção/identificação Rosa-Riobaldo, que é a mesma de um feiticeiro batizando e dando vida a seu vodu. De contrapartida, a criatura Riobaldo parece ter "possuído" o criador, a ponto de ele escrever o livro em estado de transe. Amigo íntimo de Rosa, Franklin de Oliveira acompanhou passo a passo a escritura do livro. "Rosa parecia um louco, não pensava em outra coisa. Dizia que aquilo era maior do que ele." (OLIVEIRA, 1991, p. 59). Aracy dizia que o marido levantava-se da cama tarde da noite para escrever. Esquecia-se na redação, sozinho, até o dia clarear. Possuído de tamanha energia gráfica, Rosa levou apenas sete meses para escrever GSV.

A primeira versão datilografada de GSV é um texto já organizado, articulado e coerente. É impossível imaginar que não exista uma variante ao rascunho para uma versão datilografada de 395 páginas. 0 volume está guardado na Biblioteca Brasiliana Guita e José Mindlin, na Universidade de São Paulo. É, de fato, um mistério o fato de não existir versão anterior de esboços e manuscritos. Se houve, foram destruídos. Os depoimentos unânimes de amigos próximos a Guimarães Rosa, como Franklin de Oliveira (1991) e Paulo Rónai (1991), asseguram, sem hesitação, que o rascunho de 395 páginas é o primeiro ordenamento daquilo que viria a se tornar o GSV.

Assim, toda a tessitura de imaginação e de linguagem, toda a gama psicológica de eleições e de rejeições inerentes ao processo criador, que esteve em jogo na mente do romancista, na fase antecedente a esta escritura, incorpora-se num bloco radicalmente elidido, inatingível, inconhecível (HAZIN, 1991, p. 30).

Já nesta primeira versão vemos que:

[...] as imagens são, em geral, imprevistas e estão aparentemente soltas na narrativa, isto é, não têm um encadeamento lógico por um processo associativo, insinuam um sentimento ou uma sensação, armam uma situação, concorrem para a construção de um ambiente (RIEDEL, 1962, p. 146). 
Riobaldo vodu de Rosa fala sem parar, vai e volta, pede tempo para que seu interlocutor o acompanhe. Riobaldo percebe as suas próprias ambiguidades: não sabe se encontrou ou não o diabo, no meio da encruzilhada; não sabe se o "demo" existe ou não. Pode o bem dentro do mal e o mal dentro do bem, como na história de Pedro Pindó 2 e de Maria Mutema? ${ }^{3}$ Riobaldo desenvolve um modo peculiar de lidar com o duplo (bem/mal): percebe as dualidades sem nunca radicalizá-las. Há sempre uma coisa dentro da outra. Galvão (1986) entende a história de Pedro Pindó e de Maria Mutema como contos dentro do romance. Ela cita a história de Maria Mutema para exemplificar como uma coisa sempre está dentro da outra. Encontramos poemas, canções, provérbios, citações, versos como o de Siruiz, além de onomatopeias, jogos de linguagem, palavras invertidas etc. 0 romance apresenta dentro de si multiplicidade, recursividade e complexidade, no sentido de um caos organizador. Há uma proposta de repetição intencional, a narrativa gira, volta e retorna (em "eterno retorno"): Riobaldo inicia, avança, volta e retoma. No romance, há a proposta de recomeço interno, meticulosamente pensado. Depois de narrar boa parte de sua aventura a seu ouvinte, Riobaldo diz: "[...] aqui eu podia por ponto." (ROSA, 2001, p 234) .

É a confirmação de um ponto de chegada. Uma volta foi completada no percurso. Depois, um pouco mais à frente, ele diz: "Agora, no que eu tive culpa e errei, o senhor vai me ouvir." (ROSA, 2001, p. 237). Riobaldo mostra que é preciso recomeçar, recontar sua história, para que as coisas fiquem claras. Curiosamente, no meio do livro, ele indaga-se: "Minha vida teve meio do caminho?" (ROSA, 2001, p. 235). Hazin acredita que "[...] o vezo da repetição parece inerente à psicologia de Riobaldo." (HAZIN, 1991, p. 33), obviamente "possuído" por Guimarães Rosa, o vodu Riobaldo e o próprio GSV renascem no "meio do caminho". Na versão corrente da gênese de GSV, parece haver consenso de que o livro nasceu enquanto Rosa escrevia um conto do livro Corpo de Baile, no qual estava trabalhando havia meses. E o conto foi crescendo. Cresceu até alcançar 395 páginas. 0 primeiro rascunho foi produzido entre julho de 1953 e fevereiro de 1954. De dentro de Corpo de Baile nasceu GSV. Uma coisa dentro da outra.

\footnotetext{
${ }^{2}$ A maldade pura e gratuita caracteriza desde cedo Valtei, filho de Pedro Pindó, um homem muito bom que, para corrigir o menino, começa a castiga-lo. Com o tempo, Pedro Pindó acaba sentindo prazer em oferecer castigos a Valtei (nesse caso, o bom se reverte no exercício do mal).

${ }^{3}$ Maria Mutema é uma mulher que vivia em uma vila sertaneja e que o marido amanheceu um dia morto, na cama. Enterrado o marido, ela vive sua vida de viúva digna, sempre calada e de preto. Está sempre na igreja se confessando com o Padre Ponte, homem bonachão e gordo que, com o tempo, foi emagrecendo, definhando até morrer. Um dia, padres estrangeiros chegaram ao vilarejo com a missão de reavivamento, e Mutema é interpelada por um dos padres. Depois de algumas reviravoltas, ela confessa que matara gratuitamente seu marido, introduzindo chumbo derretido no ouvido, depois confessou o crime ao Padre Ponte, dizendo que o fizera por amor a ele, o que era mentira. Quanto mais o padre sofria e definhava, mais ela insistia na mentira. Mutema vai presa e na cadeia vive de joelhos, rezando e confessando seus pecados. Com o passar do tempo, começa a virar santa (nesse caso, o mal se reverte no exercício do bem).
} 
Trata-se da obra de um "possuído". A voz de Riobaldo parece ter dominado Rosa, nos sete meses em que ele se dedicou compulsivamente à escritura do livro. Trabalhou como se estivesse mesmo "possuído" pela linguagem dos boiadeiros ou dos cangaceiros. Estava "possuído", também, de uma estética, uma energia gráfica que o fazia adotar aquela voz, expressão sintática, semântica, metafórica e poética. Riobaldo, o vodu, estava livre para dizer o que bem entendesse, além disso, estava sempre em marcha, no "meio do caminho", na "vereda". A estrada era um lugar imaginário que o escritor explorava à exaustão. ${ }^{4}$ Em Rosa, as imagens não se prendem às margens, elas flutuam, oscilam, vem e vão, sobem e descem, crescem e mínguam, abrem e fecham, elas se prendem aos desejos de imortalidade, eternidade e infinito. A órbita do imaginário Roseano é regida sobre o eterno, e talvez por isso, os homens sofram, como Riobaldo, o destino de estar "morto em vida", como observou Kamper (2010). O sofrimento do homem, segundo Kamper, é justamente o fato dele estar "morto em vida", como um vodu. 0 homem contemporâneo passa a entender o mundo a partir de imagens, e as tem como substância essencial. Por estar "morto em vida", o ser humano ilude-se na autogestão e, sobretudo na produção de novas imagens, aposta que o excesso, a continuidade e o encadeamento podem garantir a própria lógica e a continuidade da vida. A produção excessiva das imagens, em nosso tempo, obedece ao crivo da rapidez e da facilidade, bem ao contrário do que sugerem os aspectos imagísticos de GSV.

As imagens em GSV aparecem espelhadas, ambíguas e fantásticas. Observam-se ,inicialmente, os seus duplos: o romance apresenta, simultaneamente, uma matéria história (jagunços, sertanejos, fazendeiros, coronéis, cangaceiros etc.) e uma matéria imaginária (caracterizada por uma visão medieval de mundo, a força da tradição oral etc.). 0 livro é um monólogo de dupla perspectiva: o narrador é também personagem; o jagunço é também professor, aquele que conta o que viveu, assim como viveu o que conta. Riobaldo produz, além de narração, reflexão, elabora, lança imagens, qual um filósofo selvagem. ${ }^{5} \mathrm{~A}$ estrutura de GSV é também dual: um texto escrito com características de oralidade que utiliza certa erudição, mas que é popular; o narrador tem momentos de lucidez filosófica e de loucura desvairada. Sua sexualidade tem contornos bissexuais; o narrador está próximo e distante do homem sertanejo; sua concepção metafísica une espiritismo popular com as ideias do

\footnotetext{
${ }^{4}$ Ver as expedições ao interior de Minas Gerais, de Mato Grosso do Sul que Rosa se punha em marcha com sua caderneta tomando notas.

5 No sentido da "lógica do coração" de que fala María Zambrano em A metáfora do coração (ZAMBRANO, 2000).
} 
budismo e de Heráclito. ${ }^{6}$ Encontram-se em Riobaldo, a nosso ver, imagens biográficas do próprio Rosa. ${ }^{7}$ Neste artigo, a proposta é analisar as formas de apresentação das imagens em GSV, a partir de alguns trabalhos no campo da Literatura/Teoria Literária, deslocandoos intencionalmente para pensar a Comunicação e a Teoria Estética, na relação receptorobra. $\mathrm{O}$ intuito é aprofundar a noção de duplo, explorando os imaginários presentes na obra.

\section{Imaginário da indeterminação comunicacional}

É comum ouvirmos que GSV é um livro difícil de ser lido e compreendido e que não são todos os leitores que conseguem se "comunicar" com ele. É recorrente ouvirmos sobre a inadequação de leitores à sua forma, sua linguagem, que a "fala" do ambiente urbano, cotidiano e instrumental não tem aderência e proximidade com a fala sertaneja do livro, e que o texto oral de Riobaldo não é funcional. Qualquer leitor, no entanto, consegue perceber sem muito esforço que, ali, alguém conta uma história (a sua história), e que essa pessoa tem o nome de Riobaldo Tatarana. Nota-se que o narrador dá valor e sentido à sua experiência passada como jagunço/cangaceiro e, a partir desta experiência, narra o que recorda. Parece lembrar-se de muitas coisas, visto a quantidade de detalhes que evoca. Mesmo assim, sua memória, como a de todos nós, tem lapsos e recortes precisos, ângulos próprios, vazios e indeterminações, tem "buracos e acidentes" (HANSEN, 2007), assim como imagens exatas, precisas e nítidas. Pode-se perceber que a memória e o pensamento de Riobaldo se aplicam caoticamente às imagens exatas e às inexatas.

De que inexatidão, propriamente, estamos falando? Mesmo com esses lapsos, buracos, esquecimentos e acidentes, o narrador consegue passar ao leitor informações suficientes para que ele consiga seguir em frente e enfrentar a forma do livro. Caso o leitor vença a dificuldade inicial, fazendo um pacto de leitura com o autor, perceberá adiante, intuitivamente, que Riobaldo articula muito habilmente falas curtas, provisórias, faz mudanças de tom e de assunto repentinas, parece dotado de uma infinidade de livres-fluxos que se abrem em linhas e se alongam, se alternam ao sabor de sua imaginação e criatividade. É humorístico, poético, monstruoso, lírico, selvagem. E Riobaldo confunde intencionalmente seu interlocutor/receptor. No momento em que fala, o significado de sua imaginação sugere ao leitor algo que pode não corresponder exatamente àquelas imaginadas. A inexatidão faz

\footnotetext{
${ }^{6}$ Rosa inspira-se no fragmento 49, de Heráclito: "Nos mesmos rios entramos e não entramos, somos e não somos.", para ele, esta sentença é a afirmação do ser e do não-ser (HERÁCLITO, 2002).

7 Esta também é a tese de Hoisel (2006).
} 
parte da forma poética. Riobaldo é ambíguo e rápido ${ }^{8}$, produz imagens em camadas superpostas, contrapostas e abertas. Em sua fala algo se pronuncia intencionalmente dual, impreciso, fragmentado, corroído; vemos frequentemente imagens iterativas. ${ }^{9}$ Em Rosa, essas imagens iterativas desenvolvem-se crescendo em intensidade, em movimento, em complexidade, à medida que voltam ao longo da narrativa. "Esta ampliação redundante corresponde a processos intensificadores, um dos aspectos que mais caracterizam o estilo roseano." (RIEDEL, 1962, p. 146).

As imagens vão crescendo em intensidade. Hansen viu nessas imagens "deformações", "atravessamentos" e "indeterminações", descritas por ele da seguinte maneira:

0 texto de GSV é inteiramente marcado pelas imagens dos atravessamentos e deformações da linha. Por exemplo, as imagens da cachoeira, que é barranco e água, mas que não é mais, quando a água é consumida; as da mandioca doce, que vira azangada, e a da mandioca brava, que vai vir a ser mandioca mansa; a imagem da faquinha só cabo quando a lâmina é roída no tanque de barbatimão; as imagens da terra doida, lagoa de areia, do Liso do Sussuarão; as da animalidade dos jagunços do Hermógenes; a do macaco comido na fímbria do Liso e que era homem; as dos catrumanos no limiar da natureza; as imagens das Veredas Mortas, onde Riobaldo escolhe a indeterminação, querendo a força do imaginário, 'diabo', para ter o imaginário da força no seu poder de chefe. (HANSEN, 2007, p.48).

Ora, mas as imagens dos atravessamentos e deformações de linha não se aplicam justamente àquelas de "duplo"? 0 vodu de Rosa escolhe a indeterminação: "Eu era dois, diversos? O que não entendo hoje, naquele tempo eu não sabia."(ROSA, 2001, p. 460). Riobaldo admite a indeterminação, escolhe a "força do imaginário", porque percebe ali um nível de realidade adequado à sua lógica. Para Hansen, os personagens do livro estão postos nas bordas da racionalidade iluminista, gente formuladora de outra lógica. "Como se sabe, Rosa ama pra valer os capiaus iletrados, os matutos do mato, as crianças, os aluados, os débeis, os loucos, os bêbados, os poetas populares." (HANSEN, 2007, p. 34).

\footnotetext{
${ }^{8}$ No sentido que Italo Calvino (1990) chamou na proposta "Rapidez", no livro Seis propostas para o próximo milênio, a capacidade de evocação de imagens exatas (e inexatas) pela adequação da imagem à palavra.

${ }^{9}$ As imagens iterativas são aquelas que voltam ao longo da narrativa de Grande Sertão: Veredas, como: amor; encruzilhada; redemoinho; vida como perigo; travessia; diabo; sertão; veredas; coragem; medo; feminino e água. Somente o estudo da água, por exemplo, apontaria para muitas direções, como a questão do som. Cabe estudo a parte o aspecto sonoro e fônico do livro, seleção vocabulário, efeitos, onomatopeias, inversão de palavras, jogos de valor metafórico, esquemas sintáticos com valor rítmico, pontuação, etc.
} 
Quando valoriza a experiência de homens desclassificados pela cultura dominante como irrepresentáveis ou irresponsáveis sem competência para pensar e falar, a indeterminação da forma é elemento antropológico e político intencionalmente crítico, pois é meio técnico de figuração poética da experiência de um outro cultural que é plenamente apto a fazê-lo e, simultaneamente, meio avaliativo dos limites históricos das lógicas dominantes que definem as ideologias do leitor. (HANSEN, 2007, p.35).

Esses seres, como Riobaldo, que não seguem a "lógica dominante", seres "desclassificados", são figurados "pelo meio", segundo Hansen, captados pelo movimento deslizante, descem e sobem sobre a linha imaterial que separa determinado/indeterminado, ganham espaço na literatura de Rosa na posição de pensadores, como ocorre com Riobaldo em GSV. 0 "elemento antropológico e político intencionalmente crítico" (HANSEN, 2007, 35) que figura como "meio técnico" e poesia, aparece na relação tempo versus memória. 0 tempo corroeu a unidade de sua experiência de passado. Tudo o que Riobaldo diz sobre sua história é reverberação, imagens parciais e deformadas, pois o movimento do tempo consumiu, transformou, regurgitou nele novas imagens. Riobaldo fala de sua experiência em vários campos: boiadeiro, atirador, professor, jagunço, no entanto, parece preferir não refletir profundamente sobre algumas delas, como no caso de sua homossexualidade, do pacto diabólico, da perda de Diadorim, ou no caso do exercício da chefia do bando como "Urutu Branco". Muitas imagens em GSV aparecem rodeadas de não ditos. Riobaldo não pode dizer explicitamente que ama Diadorim, apesar das imagens deste amor estarem todas lá. As imagens estão dissolvidas na indeterminação dos discursos de Riobaldo.

De maneira lenta, acumulada e minuciosa, Riobaldo descreve suas sensações delineando com nitidez e semiconfusão seu mundo, que se revela errante, caótico e violento. Mostra-nos sua visão das coisas e sua concepção de mundo. Tanto em uma como na outra, não há a certeza conclusiva, as coisas não estão acabadas, e esse inacabamento é costurado, para Hansen, em GSV, numa "imagem de fundo", que traduz e une todas as outras imagens: trata-se da imagem de amor. 0 amor em GSV torna-se uma força unificadora. No relato de Riobaldo, ele aparece como força de vida. Mesmo sabendo que "viver é muito perigoso", ele enfrenta seus instintos, a dureza da vida sertaneja e a figura do "demo", representada em Hermógenes, para estar ao lado do amigo e do amor. Formam uma "dupla", e todos sabem disso. Há um entremeio, na composição das imagens, em GSV, que são análogas à composição das falas de Riobaldo: a exatidão das referências da cultura sertaneja e a exatidão das referencias da cultura ilustrada são entremeadas e justapostas. Rosa criou um caos organizado e um fluxo de si na forma e no conteúdo de seu vodu jagunço, situado entre 
duas margens, o poeta e o assassino Riobaldo. Seu fluxo narrativo e as imagens por ele evocadas, postas simultaneamente lado a lado, em uma fala/escrita que subverte a norma culta e cria, do ponto de vista comunicacional, um "contrato enunciativo", sugere complexidade imediata. Autor e leitor não estão próximos, sendo que, no caso de GSV:

\begin{abstract}
Autor e leitor estão quase sempre em pontos diferentes do tempo, por isso mesmo o intervalo cronológico e semântico entre ambos impede a identidade do leitor com o destinatário, o que produz vazios no seu entendimento, que se acrescentam aos vazios da indeterminação já efetuada na forma. (HANSEN, 2007, p. 46).
\end{abstract}

Esses vazios de entendimento na forma de GSV são estratégias de comunicação complexas e misteriosas, visto que beiram o próprio incomunicável. Esses "vazios da entendimento" ocorrem esporadicamente e funcionam, também, como estratégicas de indeterminação. As falas e as imagens suscitadas por Riobaldo produzem confusão, "deformações", dificuldades. A comunicação de Riobaldo flui labiríntica, bárbara, arcaica e indeterminada. A escritura flutua do oral para o escrito e vice-versa, do iletrado para o letrado e vice-versa, indo e vindo em jogos de entendimentos e de desentendimentos e vazios de significação. Tudo isto tem um objetivo:

Funcionalmente, as imagens da representação saem diretamente dos atos da invenção do autor. Funcionalmente, não são simples apliques elocutivos, biscuits rococós ou acessórios neo-parnasianos exteriores, mas deformações aplicadas para sugerir ao leitor que o ser das coisas representadas como 'sertão' necessariamente cai fora da sua própria representação. (HANSEN, 2007, p. 30).

Poeticamente, esses vazios de entendimento põem a significação entre parênteses. Esta técnica narrativa é, obviamente, uma experiência com a forma. Técnica materialmente calculada de dissolução da linguagem usual. Rosa recusou em GSV a linguagem instrumental, existente, sabendo que seria impossível Riobaldo se prender à clareza da lógica linear. "O mundo produzido por Rosa com os destroços das linguagens existentes é poeticamente bárbaro e arcaico." (HANSEN, 2007, p. 31). Em sua análise das "imagens de Guimarães Rosa", Hansen, entendeu que:

De Sagarana a Tutameia, Guimarães Rosa relaciona sua arte e tradição literária universal como autor de um ato estético que integra duas funções narrativas, representação, a referencia imaginária figurada ficcionalmente, e avaliação, a comunicação do ponto de vista com que o autor avalia o sentido da representação para o leitor. (HANSEN, 2007, p. 29). 
O "ato estético" de "avaliação" e "comunicação" na leitura de GSV significa assumir a "complexidade crescente" de imagens dentro de imagens, implica a necessidade de uma "transcendência estética", enseja que o leitor assuma os "vazios de entendimento" como parte da forma/recepção. Hansen propõe ler as imagens de GSV de modo funcional, entendendo-as como especificidades de estilo. As imagens são vidências e evidências dos processos retóricos que constituem o romance, na variação da forma, a intencionalidade autoral que "avalia" e "comunica" ao leitor segundo um sentido objetivamente complexo. No GSV, a integração de representação da fábula e a linguagem aplicada relacionam-se ao imaginário e aos procedimentos técnicos, sem perder a tensão contínua da indeterminação da comunicação (HANSEN, 2007).

\section{Imaginário da ambiguidade}

Walnice Nogueira Galvão dedicou sua tese de doutorado (1986) para pensar as imagens da ambiguidade em GSV. No sugestivo título As formas do falso: um estudo sobre a ambiguidade em Grande Sertão: Veredas (GALVÃO, 1986), Galvão parece ter esgotado o assunto ao mostrar como GSV é um livro que oscila entre a linearidade, como se fosse uma 'história de jagunços', e a não linearidade, a confissão de um narrador cuja tensão interior transcende a simples vida sertaneja. A ambiguidade está, também, no fato de que por baixo de uma narrativa realista, esconde-se o fantástico e o metafísico. 0 duplo ou a ambiguidade aparece no personagem Diadorim/Deodorina. 0 imaginário da ambiguidade é o "princípio geral da reversibilidade" (CANDIDO, 1964), a força mesmo que preside a narrativa de GSV. Sobre a base concreta de uma história de jagunços se elabora um romance de cavalaria; a partir de uma história de amor encontra-se uma narrativa de guerra pelo fim da jagunçagem no sertão entre Minas, Goiás e Bahia.

Sobre a massa de símbolos evocados no romance, elabora-se uma história faustica, pactária e diabólica. 0 sertão não é Minas, mas o mundo. 0 duplo em GSV revela-se de outras formas: as coisas são e não são simultaneamente. Há um lado negativo e um lado positivo, e Riobaldo oscila, o tempo todo, entre um e outro. Tudo isto está trançado de tal maneira, segundo Candido (1964), que há uma impossibilidade de definir o que é e o que não é. Se a esquerda é o lugar do mal e a direita do bem ou vice-versa. Coisas boas ocorrem à esquerda e coisas más à direita. Há a divisão teórica do mundo, mas tudo, imediatamente, se embaralha: Riobaldo é aclamado como libertário: o homem que acabou com a jagunçagem 
no sertão, mas o que ele é senão um jagunço? 0 duplo, o paradoxo e o "deslizamento de sentido" tem em Diadorim seu símbolo máximo. Rosa elabora o jagunço como uma forma de ser, vê nele um drama ontológico. Em seguida, vem o pacto e, a partir daí, o que é impossível se torna possível: a travessia do Liso do Sussuarão parecia lugar intransponível, mesmo assim, após o pacto, eles atravessam. 0 duplo está na estrutura do romance, no enredo, nos personagens, na concepção metafísica e nos comentários marginais do narrador.

Em Riobaldo, duas humanidades se comunicam e se entrelaçam: o homem real, o sertanejo e o homem fantástico, vidente, quase sobrenatural. Na batalha final do GSV, a batalha do Tamanduá-tão, ele vence sem sair do lugar. Fica montado no cavalo, guerreia sem se mexer. 0 poder da vontade e o poder mágico que adquiriu com o pacto tem a capacidade de desviar balas. 0 pacto é, também, um elemento de ambiguidade: ele foi ou não foi realizado? No fundo, Riobaldo não sabe. Seria ele mesmo um vodu do diabo? Outras ambiguidades revelam-se ao longo da narrativa: Zé Bebelo, vencido e capturado, que devia ser sacrificado, é liberto; Diadorim, que devia ser homem, é mulher. A ambiguidade aparece na própria obra. O livro de Rosa, afinal, era literatura regional ou universal, ou ambas? Livro de exuberância verbal, ficção de tipo universal, com os problemas do homem; regionalismo que não é regionalismo; universalidade que é a mais particular possível; Rosa fez um livro no qual o poeta está no jagunço, a mulher no homem e o diabo em Deus.

A ambiguidade e as formas do falso, o fictício, o verdadeiro estavam tanto nas preocupações teóricas e estéticas de Walnice Nogueira Galvão (1986) quanto nos ensaios críticos de Carlo Ginzburg (2007), em O fio e os rastros. Trata-se de reflexões sobre o "verdadeiro, o falso e o fictício", quando, ao pensar no trabalho de reconstrução histórica, entende-a como "uma contenda pela representação da realidade".

Contra a tendência do ceticismo pós-moderno de eliminar os limites entre narrações ficcionais e narrações históricas, em nome do elemento construtivo que é comum a ambas, eu propunha considerar a relação entre umas e outras como uma contenda pela representação da realidade. Mas, em vez de uma guerra de trincheira, eu levantava a hipótese de um conflito feito de desafios, empréstimos recíprocos, hibridismos. (GINZBURG, 2007, p. 9).

Entre esses "desafios" e "empréstimos" está a de explorar a noção de "vereda" para pensar/problematizar este "espaço intermediário" no gigantismo do sertão. Esse "espaço intermediário" está entre duas margens, e ele mesmo é outra margem. Radicalmente entre, encravado no meio geográfico, exige travessia, ir e vir nem sempre confortável, calculável e 
pré-determinado. É neste meio, "entre", que as realidades e suas representações se misturam, se enfrentam, "contenda" de realidades, "desafios" e "empréstimos recíprocos". 0 próprio Rosa fez "empréstimo" de temas de outras obras. Como se sabe, GSV foi lançado em 17 de julho de 1956, um volume grosso, com 594 páginas, e veio a público inspirado em três temas centrais:

a) A Balada de Mulan - conto chinês que narra a história de um velho que tendo sido ultrajado e não tendo nenhum filho varão, é vingado por uma das filhas que, disfarçada de homem, não é reconhecida até o final da história. Na Europa medieval, a história ficou conhecida como A donzela que foi à guerra;

b) Doutor Fausto, de 1947, Thomas Mann - o tema do diabo e do pacto era algo que frequentava as ideias de Rosa desde a juventude;

c) Ontologia e psicologia dos jagunços - Rosa leu bastante sobre a história de velhos coronéis do sertão, cangaceiros e jagunços. Ele queria mostrar um jagunço diferente, se preocupava que esses homens fossem vistos apenas como seres sanguinários, vingativos, sem estofo existencial ou metafísico. Era preciso revelar o drama existencial desses homens, seus anseios e suas angústias.

GSV está construído a partir de uma "dialética da afirmação e da negação" (BRUYAS, 1983, p. 460): se por um lado afirma algo, por outro lado o nega. Contudo, não se trata, na visão de Bruyas, de uma solução em termos de mistura banal, mas de uma dialética sem síntese.

\section{Imaginário das misturas}

A imaginação de Rosa subtrai o livro de sua matriz regional, para fazer falar os grandes temas: o amor, a morte, a amizade, a vingança, a guerra, deus e o diabo. 0 imaginário da mistura de histórias, personagens e narrativas, a mescla entre realidade e invenção, ou, em outras palavras, entre história e mito, é o que Arrigucci Júnior (1994) afirma ser constitutivo GSV. Segundo ele, o livro é constituído a partir do "princípio da mistura" que está "[...] em consonância com o processo histórico-social que rege a realidade também mesclada do sertão rosiano." (ARRIGUCCI JÚNIOR, 1994, p. 7). A questão que o exjagunço se coloca é: “Por que foi que eu conheci aquele menino?” (ARRIGUCCI JÚNIOR, 1994, p. 26). Para Arrigucci, essa pergunta corresponde à singularização do herói do romance, pois dá a dimensão da experiência individual que o diferencia e o afasta da comunidade dos homens e das narrativas da tradição oral. 
Há tanta mistura que a questão da descontinuidade de imagens e da fragmentação da narrativa predomina em, pelo menos, dois terços do livro. 0 sem sentido exacerba-se. Está presente na violência sem razão, inexplicável e incompreensível, como no episódio da matança dos cavalos na Fazenda dos Tucanos, levada a cabo pelo bando do Hermógenes, a quem o grupo de Riobaldo combatia. 0 experimentalismo linguístico de Guimarães Rosa é uma tentativa de protestar contra a língua deteriorada pela comunicação de massa e aparentemente contra certas teorias da comunicação. Em GSV, a forma significante insiste em ficar indeterminada, o sentido não se revela de forma unívoca, permanecendo sempre em suspensão.

Nesta estética da mistura de Rosa, "pedaços de coisas incompossíveis se atritam" (HANSEN, 2007, p. 47), como na caracterização do Hermógenes, na qual são utilizados predicativos como "caramujo, tigre, cavalo, jiboia, cão, irara, suindara" (HANSEN, 2007, p. 48). Com tantas imagens de animais juntas, elas acabam não predicando, o sentido desliza de um significado a outro e não se fixa em nenhum. Para Hansen (2007), a questão não é a "mistura" que pressupõe que duas ou mais coisas se mesclem entre si para formar uma terceira. Na sua visão, não há uma terceira coisa unificada que resulte da mescla, não há uma "intimidade mais funda da obra" em que um sentido unitário se revele, mas há indeterminação, possibilidade de ser muitas coisas ao mesmo tempo, em uma palavra, complexidade.

Apenas dois anos antes de começar a redação de GSV, Rosa acabara de ler Ilíada. ${ }^{10}$ Na sua leitura, prestou atenção a Aquiles que se disfarçava de mulher para não ir à guerra. Em GSV, é o contrário o que ocorre: Diadorim se disfarça de homem para ir à guerra. 0 que aproxima os dois livros é uma concepção mítica e lendária de história. Como na Ilíada, em GSV, os rios são mais do que acidentes geográficos. No poema de Homero, o rio Scamandro aparece como um Deus, filho de Zeus, é uma força superior, em que a cólera o faz transbordar. Da mesma forma, Guimarães Rosa não mostra o rio Urucuia e o rio S. Francisco como acidentes físicos, mas como realidades mágicas, cursos d'água e deuses fluviais, eles mesmos "veredas" nas grandezas do sertão. Tanto em um, como no outro há a divinização da natureza, o animismo e o politeísmo.

O duplo, a indeterminação, a ambiguidade e a mistura são alguns dos aspectos imaginários de GSV. São, também, utilizados pelo autor como pressupostos poéticos,

\footnotetext{
${ }^{10}$ Rosa fizera a releitura em Paris, em 1950. Lera a primeira vez em Hamburgo, entre 1938 e 1942. A Ilíada é poema épico da Grécia antiga, escrito por Homero, que narra os últimos 50 dias do décimo e último ano da Guerra de Tróia.
} 
enfrentamentos com o simbólico, que representam, por sua vez, enfrentamento com o diabólico, sendo que esse enfrentamento cria não um novo símbolo, mas um "entremeio", um "espaço intermediário" indeterminado. Ao borrar as pistas e o fácil entendimento em GSV, Rosa afirma o primado da intuição estética, irredutível ao racionalismo das linguagens instrumentalizadas. Hansen observa que as oposições racionalistas desaparecem nos efeitos poéticos de indeterminação. Para Riedel (1962), em GSV, "as imagens espaciais do infindável não se separam das imagens da perfídia". 0 infinito não se separa do banal, o "grande" está na "vereda", o Aberto é como o Sertão: "está em toda parte" (ROSA, 2001,p 30).

Quando deforma as imagens, o léxico, a sintaxe e a semântica, essas deformações deslocam o sentido em outra direção: de suspensão poética e mística. No plano místico, GSV é a ascese ${ }^{11}$ de Riobaldo, sua via de enfrentamento do mal. No plano teológico, ele diz: "beber de toda água". Há similaridade entre homens, vias, rios, sentimentos e emoções. Proença viu o rio Urucuia espelhado na figura de Riobaldo e entendeu Otacília como o remanso do rio, a curva onde Riobaldo se acolhe. Proença entende que há um imaginário das águas em GSV, ao associar "a correnteza do rio" a Diadorim. "Riobaldo transfere para o rio a função de purificação." (PROENÇA, 1958, p. 34). 0 rio é o Aberto: o "[...] mistério que se associa à morte, a eternidade, ao fim de tudo, quando a vida deságua no infinito." (PROENÇA, 1958, p. 34). Trata-se da retomada por Rosa da velha imagem heraclitiana da travessia. A travessia aponta o infinito, imprevisto destino, a própria indeterminação do Aberto:

Eu atravesso as coisas - e no meio da travessia não vejo! - só estava era entretido na ideia dos lugares de saída e de chegada. Assaz o senhor sabe: a gente quer passar um rio a nado, e passa; mas vai dar na outra banda é num ponto muito mais em baixo, bem diverso do que em primeiro se pensou. Viver nem não é muito perigoso? (ROSA, 2001, p. 65).

O valor simbólico da água reforça a temática de existência e do destino do homem, oferece imagens para a problemática do bem e do mal, para sentimentos, emoções e sensações. A natureza é sempre fonte de muitas imagens, que dão força a um processo de abstração; são frequentes as comparações dos estados internos com os processos da natureza, em uma união do homem com o universo. Estas abstrações são imagens quase místicas, um sertão profundo e inexplicável, repleto de vazios, mas não traiçoeiro e

\footnotetext{
11 Prática de origem grega, caracterizada pelo esforço, austeridade e autocontrole do corpo e do espírito, que acompanham e fortalecem a busca da verdade.
} 
agressivo, como o visto em GSV. Entre imagens fantásticas e caóticas surge uma visão dinâmica e complexa das coisas.

\section{Conclusões}

0 rio, as vias, as "veredas", trançadas no interior do sertão, em toda a sua grandeza, são as linhas do infinito, o "espaço intermediário", o entre-das-coisas, das grandes e pequenas coisas. A imensa fragmentação narrativa, multiplicada pelas imagens geradas, consolida, a partir da complexidade e da multiplicidade, um imaginário do difícil, do labiríntico e do perigoso. A partir deste ponto, a literatura de Rosa se reverte em um pensamento comunicacional vigoroso e atual. 0 entre-das-coisas, o "entremeio" situa-nos no ventre delas, novamente, uma coisa dentro de outra, como a bala dentro da cabeça de Felisberto ou na frase de Riobaldo: "O sertão é dentro da gente" (ROSA, 2001, p. 293), com o diabo junto, no "meio do redemunho", o mote: "o diabo na rua, no meio do redemoinho" (ROSA, 2001) é uma afirmação de violência comunicacional.12 0 diabo vige dentro do homem, mas também dentro de todos os processos e de todos os seres da natureza.

Esta violência pode ser situada desde os ruídos selvagens dos "entremeios" e dos contornos comunicacionais, até a tentativa de contato e de evocação do diabólico. Não é novidade para ninguém que os "poderes" comunicacionais estão associados, no campo das técnicas jornalísticas, à imagem da "pirâmide invertida", índice da afirmação do negativo. As imagens da exatidão e da inexatidão, por sua vez, mesclam-se na própria concepção existencial de Riobaldo: "No real da vida, as coisas acabam com menos formato, nem acabam. Melhor assim. Pelejar por exato, dá erro contra a gente. Não se queira. Viver é muito perigoso" (ROSA, 2001, p. 82). Em sua reflexão sobre o real, o tema do "entremeio" retorna como o que "mistura" e o que "indetermina": "O real não está na saída nem na chegada: ele se dispõe para a gente é no meio da travessia." (ROSA, 2001, p. 62-63).

O "entremeio" é uma noção comunicacional em que o espaço do contraditório e a busca pela plenitude de consciência e de abertura predominam ao passo que sugere a ampliação de limites. 0 "entremeio" mantém-se afastado das bordas, flutuando ou oscilando nesse instar, um estado dinâmico, movente, transitante, em várias direções, uma verdadeira "briga de ventos". Tal noção nos ajuda a pensar aquilo que Walter Benjamin chamou de

\footnotetext{
12 Resta ao homem lutar e "enfrentar" seus instintos, os símbolos que se apresentam, ou lutar conta o demo-mundo. Na comunicação, resta enfrentar a incerteza das encruzilhadas, das relações e do amor. Lutar contra os pactários, "enfrentar" o medo e insegurança.
} 
"limiar". Em seus últimos anos de vida, Guimarães Rosa estava justamente lendo Walter Benjamin. Assim como o limiar, o "entremeio" é uma zona, um espaço de mudança, passagem e flutuação. É justamente esse sentido de fronteira, típico das passagens parisienses, dos umbrais das portas, das porteiras, das janelas que demarcam tanto o interior quanto o exterior, o presente e o passado, o tempo e a memória. 0 "entremeio" remete às viagens e aos desejos, aos fluxos e contrafluxos; aponta para um lugar e um tempo "intermediários", relaciona-se aos processos éticos, estéticos e místicos: significa expor-se ao desconhecido e enfrentar as vicissitudes da história.

De certo modo, o imaginário é o próprio "entremeio" entre os processos racionalizantes e os sensitivos. Entre o entendimento e a sensação/percepção existe um espaço/tempo intermediário e indeterminado, de difícil entendimento, que sabemos ser germinativo, caótico, essencial; espécie de oco não oco, como o ovo que abriga "nos seus vazios", devir, avessos e duplos. Semelhante à cabeça do jagunço Felizberto, que guarda uma bala, ou às práticas de Maria Mutema, que abrigava em si o bem e o mal. 0 mal, também, se revelou um duplo: ato concreto/diabólico (matar o marido introduzindo chumbo pelo ouvido) e ato abstrato/simbólico, comunicativo (introduzindo mentiras no ouvido do Padre Ponte). A violência comunicacional está tanto no crime concreto, como no crime abstrato. A ideia de que o mal entra pelos ouvidos é outra imagem iterativa em GSV. Para se ater apenas a uma passagem, ao ouvir Hermógenes conversando, Riobaldo se apressa em dizer: "Meus ouvidos expulsaram para fora a fala dele." (ROSA, 2001, p. 293).

O imaginário em GSV aponta para a necessidade de compreensão de outra lógica, criticamente exposta pelo vodu Riobaldo. Riobaldo foi o filósofo selvagem que Rosa utilizou para dizer coisas pessoais, mas Rosa também serviu de porta-voz mediúnico do próprio Riobaldo, em uma circularidade retroativa em que o duplo se mistura e forma o inexato, o indefinível e o indeterminado. Um toma forma do outro, um dentro-do-outro. A preocupação temática de Rosa com a questão do "meio" circunda, até mesmo, o polêmico tema do mediunismo: a sensibilidade do artista faz com que ele diga e repita, muitas vezes, que estava "possuído": “Os caboclos 'baixaram' em mim... Só escrevo altamente inspirado, como que 'tomado', em transe. Aquele livro [GSV] me cansou fisicamente. Acabei extenuado. Deume, porém, enorme prazer.", conforme carta de 1966 (DANTAS, 1975, p. 28).

Em outro momento, no prefácio Sobre a escova e a dúvida, de Tutameia irá dizer que o livro foi "ditado, sustentado e protegido por forças ou correntes muito estranhas" (ROSA, 2009, p. 211). A compreensão destas "forças estranhas" e deste mediunismo de Guimarães 
Rosa não pode ser entendido como simples alegoria de um poeta-feiticeiro. Trata-se de uma abertura à compreensão do escritor, diferente daquela que tivemos até agora. Rosa faz uma literatura que discute, entre outras coisas, a comunicação e o incomunicável, justamente, porque vive neste "espaço intermediário", vereda crítica, dupla, situado entre dois mundos, artista e pensador da "terceira margem" que pode ser agregado como referência (filosófica, artística e imaginária) para os estudos da comunicação.

\section{Referências}

ARRIGUCCI JÚNIOR, D. 0 mundo misturado: romance e experiência em Guimarães Rosa. Novos Estudos CEBRAP, São Paulo. n. 40, p. 7-29, nov. 1994,.

BAITELLO JÚNIOR. N. A era da iconofagia. São Paulo: Hacker, 2005.

BRUYAS, J. Técnica, estruturas e visão em Grande sertão: veredas. In: COUTINHO, E. (Org.). Guimarães Rosa. Rio de Janeiro: Civilização Brasileira, 1983. p. 458-477. (Coleção Fortuna Crítica, 6).

CANDIDO, A. O Homem dos avessos. In: CANDIDO, A. Tese e antítese. São Paulo: Companhia Editora Nacional, 1964.

CALVINO, I. Seis propostas para o próximo milênio. São Paulo: Cia das Letras, 1990.

DANTAS, P. Sagarana emotiva - cartas de João Guimarães Rosa [a] Paulo Dantas. São Paulo: Duas Cidades, 1975.

GINZBURG, C. 0 fio e os rastros. Verdadeiro, falso, fictício. São Paulo: Companhia das Letras, 2007.

GALVÃO, W. N. As formas do falso. 2. ed. São Paulo: Perspectiva, 1986.

HAZIN, E. A. L. No nada, o infinito. Da gênese de Grande Sertão: Veredas. Tese (Doutorado em Letras) - Universidade de São Paulo, São Paulo, 1991.

HEIDEGGER, M. Para quê poetas? In: HEIDEGGER, M. Caminhos de floresta. Lisboa: Fundação Calouste Gulbenkian, 1998.

HERÁCLITO. Fragmentos contextualizados. Rio de Janeiro: Difel, 2002.

HANSEN, João Adolfo. Forma, indeterminação e funcionalidade das imagens de Guimarães Rosa. In: SECCHIN, Antonio Carlos et al. (Org.). Veredas no sertão rosiano. Rio de Janeiro: 7Letras, 2007. p. 29-49.

HOISEL, E. Grande Sertão: Veredas - uma escritura biográfica. Salvador: Academia de Letras da Bahia, 2006.

KAMPER, D. Imagem. In: CASTRO, G. Mídia e imaginário. São Paulo: Annablume, 2010. 
MORIN, E. Cultura de massa no século XX. Rio de Janeiro: Forense universitária, 2005.

MICHAELIS. Moderno dicionário da língua portuguesa. São Paulo: Companhia Melhoramentos, 1998.

OLIVEIRA, F. [Entrevista]. In: HAZIN, E. A. L. No nada, o infinito. Da gênese de Grande Sertão: Veredas. Tese (Doutorado em Letras) - Universidade de São Paulo, São Paulo, 1991.

PROENÇA, M. C. Trilhas no grande sertão. Rio de Janeiro: Ministério da Educação e Cultura, 1958. (Cadernos de Cultura, 114).

RIEDEL, D. C. Aspectos da imagísticas em Guimarães Rosa. Tese (Cátedra) - Faculdade de Filosofia, Ciência e Letras, Universidade Estado da Guanabara, Rio de Janeiro, 1962.

RÓNAI, P. [Entrevista]. In: HAZIN, E. A. L. No nada, o infinito. Da gênese de Grande

Sertão: Veredas. Tese (Doutorado em Letras) - Universidade de São Paulo, São Paulo, 1991.

ROSA, J. G. Grande Sertão: Veredas. Rio de Janeiro: Nova Fronteira, 2001.

ROSA, J. G. Tutameia. Rio de Janeiro: Nova Fronteira, 2009.

ZAMBRANO, M. A metáfora do coração. Lisboa: Assírio \& Alvim, 2000.

\title{
Aspects of imagery and communication in
} Grande Sertão: Veredas

\begin{abstract}
A critical reading of the images from Grande Sertão: Veredas (from 1965), with emphasis on the communicational and the uncommunicational aspects. The imaginary of the book oscillate among images of indeterminacy, ambiguity, and a mixture of "innermedium", i.e., "things-within-things" and "things-inbetween-things". Thus, the paper discusses the aesthetical connection between the reader and the reading of the book. The analysis is based on the book poetic form and gives rise to considerations on imaginary theory and communicational thought.
\end{abstract}

\section{Keywords}

Brazilian literature. Comunication. Grande Sertão: Veredas. Guimarães Rosa. In between. 